\section{RISUS}

- Journal on Innovation and Sustainability
ISSN 2179-3565

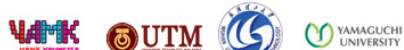

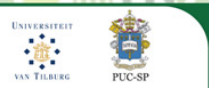

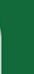

RISUS - Journal on Innovation and Sustainability volume 9, número 1 - 2018

ISSN: 2179-3565

Editor Científico: Arnoldo José de Hoyos Guevara Editora Assistente: Lívia Lopes Aguiar

Avaliação: Melhores práticas editoriais da ANPAD

\title{
ROLE OF NORMATIVE PRESSURES TO ADOPT GREEN SUPPLY CHAIN MANAGEMENT PRACTICES AND THEIR IMPACT ON ENVIRONMENTAL AND ECONOMIC PERFORMANCE
}

\author{
Práticas de Gestão e seu Impacto no Desempenho Ambiental e Econômico
}

\author{
Amer Saeed $^{1,2}$, H.P. Rasika Priyankara ${ }^{1,3}$, N.P.G.S.I. Naotunna ${ }^{3,4}$ \\ 1 School of Management, Wuhan University of Technology, Wuhan, P.R.China \\ 2 University of Management and Technology (UMT), Lahore, Pakistan. \\ 3 Faculty of Management Studies, Sabaragamuwa University of Sri Lanka, Belihuloya, Sri Lanka. \\ 4 Huazhong University of Science and Technology, Wuhan, P.R. China, 430070 \\ E-mail: amersaeed@whut.edu.cn, rasikahp@ymail.com, shashinaotunna@ymail.com
}

\begin{abstract}
Businesses around the globe are facing tremendous pressures to improve their manufacturing practices to minimize their harmful effects on the environment. These pressures are being exerted from different stakeholders but in developing countries mostly there are powerful suppliers and customers, which can change the choices of decision makers in the local industry. According to institutional theory these pressures combined are called normative pressures. By using path modeling this study attempted to find out the role of normative pressures to adopt green supply chain management (GSCM) practices and the impact of those adopted practices on environmental and economic performance of those companies through partial least square (PLS) structural equation modeling (SEM). Data was collected from 134 manufacturing companies in Pakistan through a questionnaire. Path analysis results confirmed that normative pressures have positive and significant impact on adopting the GSCM practices and subsequently these practices improve the environmental performance of the companies in Pakistan. Results also confirmed many existing studies that GSCM practices directly do not improve economic performance but environmental performance does have a significant positive effect on the economic performance
\end{abstract}

Key words: Normative pressures; Green supply chain management practices; Environmental performance; Economic performance; Pakistan

Resumo: Empresas em todo o mundo estão enfrentando enormes pressões para melhorar suas práticas de fabricação para minimizar seus efeitos nocivos sobre o meio ambiente. Essas pressões estão sendo exercidas por diferentes partes interessadas, mas nos países em desenvolvimento existem principalmente fornecedores e clientes poderosos, que podem mudar as escolhas dos tomadores de decisão na indústria local. Segundo a teoria institucional, essas pressões combinadas são chamadas de pressões normativas. Com a modelagem de caminhos, este estudo buscou descobrir o papel das pressões normativas na adoção de práticas de gestão da cadeia de suprimentos verdes (GSCM) e o impacto dessas práticas adotadas no desempenho ambiental e econômico dessas empresas através da modelagem de equações estruturais(SEM) utilizando minimos quadradas (PLS). Os dados foram coletados de 134 empresas de manufatura no Paquistão por meio de um questionário. Os resultados do Path Analysis confirmaram que as pressões normativas têm impacto positivo e significativo na adoção das práticas de GSCM e, posteriormente, essas práticas melhoram o desempenho ambiental das empresas no Paquistão. Os resultados também confirmaram muitos estudos existentes de que as práticas de GSCM não melhoram diretamente o desempenho econômico, mas sim o desempenho ambiental que tem um efeito positivo significativo sobre o desempenho econômico.

Palavras-chave: Pressões Normativas; Práticas de Gestão da Cadeia de Suprimentos Verdes; Desempenho Ambiental; Desempenho Econômico; Paquistão

Recebido em: 27/03/2017

Aceito em: 01/03/2018 


\section{INTRODUCTION}

Globalization have not only made this world a global village but also changed the life style, needs, requirements and consumption patterns of billions of people (Amer, Yun and Priyankara, 2016). Modernization of industry was a solution to fulfill this ever changing and increasing demand of customers but at the cost of negative impact on environment (Geng, Mansouri and Aktas, 2017). Different stakeholders including but not limited to government agencies, international regulatory bodies, main suppliers, customers, NGO's and competing organizations are main sources of motivation to bring change in traditional manufacturing processes (Zhu, Sarkis and Lai, 2013). To face this challenge now companies are thinking strategically to incorporate green supply chain management (GSCM) practices with an intention to minimize harms to the environment and increase profitability by achieving a competitive advantage (Vanalle, et al., 2017; Gopal and Thakkar, 2016). All these pressures are divided into three categories by institutional theory and the pressures related to main suppliers, customers and from international regulatory bodies for export oriented companies are called normative pressures and for businesses operating in developing countries these are the most important type of pressures to pursue GSCM practices (Amer, et al.,2016; Zhu and Geng, 2013). Many studies have confirmed the improvement in environmental performance (Gopal and Thakkar, 2016;Zhu and Geng, 2013;Zhu, Sarkis and Lai, 2007) by adopting GSCM practices but for direct improvement in economic performance there are mixed results. Some studies have found significant positive effect (Zhu, et al., 2007) while others found no or negative effect $t$ (Zhu, et al., 2013;Esfahbodi, et al., 2016). Similarly, improvement in economic performance due to improved environmental performance has also been reported by many authors(Zhu, et al., 2013; Vanalle, et al., 2017;Gopal and Thakkar, 2016;Esfahbodi, et al., 2016).

All above mentioned studies are from developed or large industrial countries. To make this world free of environmental degradation in every country whether developed or developing, every industry whether big or small should positively contribute for sustainability goals. By using institutional theory, this paper aims to follow guideline of (Geng, et al., 2017) to study the role of normative pressures on GSCM practices of organizations and subsequent effects in terms of performance in other regions especially in Pakistan, a developing country in South Asia. Current study is an attempt to find answers of following two research questions.

1) Do normative pressures influence manufacturing companies in Pakistan to adopt GSCM practices?

2) What is the effect of GSCM practices implementation on environmental and economic performance?

\section{LITERATURE REVIEW Normative pressures}

Organizations want to prove their legitimacy by adopting certain norms and practices of a specific sector. They make strategic decisions because of institutional pressures to improve environment friendly production (Zhu, et al., 2007). Internet and social media has developed an awareness about eco-friendly products among the customers from any country and social setup (Amer, et al., 2016). Every company wants to build a green image and they cannot do it so alone as every product has to pass through a long supply chain and all the members should follow the green practices (Gopal and Thakkar, 2016). 
So, the pressures being exerted by suppliers, customers, media and NGO's are the most important motivators to adopt GSCM practices in developing countries (Zhu, et al., 2013, Mani, et al., 2016). Government regulations (coercive pressures) are not that much effective in developing countries because of non-implementation of rules due to corruption, nonavailability of resources and lack of interest by the officials (Amer, et al., 2016, Zhu and Geng, 2013).So, this study is an attempt to explore the existence of normative pressures and their influence on manufacturing companies of Pakistan. With this backdrop we posit the following hypothesis.

H1: Normative pressures positively influence manufacturing companies of Pakistan to adopt GSCM practices.

\section{GSCM practices}

GSCM is adding environmental focus in each and every level and process of a traditional supply chain which focuses on the business processes and activities from point of origin to consumption while delivering any product or service(Esfahbodi, et al., 2016). There are many terms and definitions for GSCM but the most commonly accepted and used term is triple bottom line (TBL) which guides to focus on environment, economy and social aspects of any supply chain (Hoejmose, Grosvold and Millington, 2014). The main focuses of TBL are to minimize toxic wastes, harm to environment and human health, minimize the use of natural resources (Gopal and Thakkar, 2016);2) to improve the profitability by cost reduction through improved eco-friendly product designs that use useless materials and recycled materials (Rao and Holt, 2005) and ;to improve the working conditions for employees and benefits to the society at large (Mani, et al., 2016). For manufacturing companies in developing countries with less R\&D budgets the best way to reach TBL targets is to focus on those existing set of practices such as lean practices, continuous improvements, Eco design practices, risk management and ethical behaviors (Gopal and Thakkar, 2016).

\section{Environmental performance}

Literature studying the impact of GSCM practices on environmental performance is increasing and we are getting more evidence now that there is a positive impact on the overall improvement in the environmental performance(Esfahbodi, et al., 2016, Hoejmose, et al., 2014). This seems possible because of the improved collaborative efforts between suppliers, manufacturers and customers for highly eco-friendly designs through the use of more innovative technologies (Lee, Tae Kim and Choi, 2012).

\section{Economic performance}

This area of research is quite blurry though there are many studies on GSCM practices and economic performance. There is no universal agreement on the effect of GSCM and economic performance (Rao and Holt, 2005). Since there exist a huge divide between the positive and negative or no effects at all (Zhu, et al., 2013, Vanalle, et al., 2017). This situation calls for more focus on finding the relationship between GSCM practices and economic performance of the firm. Thus, this study will also try to find out the impact of GSCM practices adoption on economic performance of Pakistani manufacturing companies. From above discussion we framed following hypotheses. 
H2a: GSCM practices are directly and positively associated with environmental performance.

H2b: GSCM practices are directly and positively associated with economic performance.

Many studies have stated that there is a strong positive relationship between environmental performance and economic performance(Amer, et al., 2016, Gopal and Thakkar, 2016, Mani, et al., 2016). Main reasons can be divided into two categories. First is less usage of natural resources, improvement in energy efficiency, less greenhouse gas emissions and solid waste reduction. Secondly improved productivity and overall sales. With this backdrop we posit the following hypothesis

H3: Environmental performance is directly and positively associated with economic performance.

\section{METHODS}

A questionnaire was developed for the collection of empirical data. Questionnaire consisted of three sections. First section contained items asking about level of normative pressures respondents are facing to adopt GSCM practices. Second section obtained responses on current level of GSCM practices adoption and the third section measured the level of environmental performance and economic performance. Respondents of this questionnaire were managers from manufacturing companies listed in Lahore chamber of commerce and industries. Emails were sent to 632 companies listed in sectors of textile, leather, pharmaceuticals and paper \& board manufacturers. These sectors were chosen, as they are most relevant with this study with respect to impact on environment and contribution to Pakistan economy. Emails were consists of a cover letter to explain the purpose of this research and a link to online survey form. Two reminder emails were sent after first and second month to request for a response from non-respondents till that time. A total of 158 responses were received out of which 134 were found to be suitable for final analysis.

Questionnaire was developed by adopting measures from already validated scales. 7 items scale on normative pressures was taken from(Lee, et al., 2012) and questions were answered using a 5-point Likert-type scale where (1= Unimportant; $2=$ Somewhat Unimportant; $3=$ Neutral; 4= Somewhat Important and 5= Very Important). GSCM Practices ( $1=$ Not at all implemented; $2=$ Mostly not implemented; $3=$ No Idea; $4=$ Mostly implemented and 5= Fully implemented), environmental performance and economic performance constructs were adopted from(Gopal and Thakkar, 2016), where $(1=$ Not at all; $2=$ Very Little; $3=$ Neutral; $4=$ More Often and $5=$ Very Frequently). SmartPLS 3.2.4 (Ringle, 2015) software was used to analyze data with structural equation modeling using partial least squares.

\section{Reliability and Validity}

As per (Hair, Ringle and Sarstedt, 2011) PLS-SEM is a two-step approach and it separately calculates measurement model and the structural model. First of all reliability and validity of defined measures should be examined. Composite reliability (CR) for internal consistency reliability should be higher than 0.7 . Indicator reliability is confirmed through item loadings higher than 0.7. AVE values for the constructs should be more than 0.5 to confirm convergent validity. Finally, to test the discriminant validity it should be confirmed that no correlation of any construct with other constructs is higher than the AVE of that construct (Hair Jr, et al., 2016, Peng and Lai, 2012). Few items (pressures $3,6 \& 7$, practices $1 \& 2$ and econperf1) with lower loadings were dropped to get all reliability and validity measures according to the threshold values. Table 1 shows all the values fulfills the minimum criteria with Cronbach $\alpha$ 's from 0.716 to 0.775 , CR values from 0.805 to 0.870 , AVE from 0.508 to 0.690 . Similarly all item loadings are above 0.7 . While square root of AVE on the diagonal in table 1 confirms the values for discriminant validity test. 
Table 1 Statistical Quality Indicator

\begin{tabular}{lccccccccc}
\hline & AVE & CR & R2 & Alpha & & EconPerf & EnvtPerf & Practices & Pressures \\
\hline EconPerf & 0.690 & 0.870 & 0.375 & 0.78 & EconPerf & $\mathbf{0 . 8 3 1}$ & & & \\
EnvtPerf & 0.542 & 0.825 & 0.042 & 0.72 & EnvtPerf & 0.609 & $\mathbf{0 . 7 3 7}$ & & \\
Practices & 0.597 & 0.816 & 0.202 & 0.71 & Practices & 0.191 & 0.204 & $\mathbf{0 . 7 7 3}$ & \\
Pressures & 0.556 & 0.833 & 0 & 0.74 & Pressures & 0.127 & 0.308 & 0.438 & $\mathbf{0 . 7 4 6}$ \\
\hline
\end{tabular}

\section{RESULTS}

Path modeling is used to test the sequential relationship between normative pressures $\rightarrow$ GSCM practices $\rightarrow$ Performance in the structural equation model. Figure 1 shows the path diagram with standardized coefficient $(\beta)$ and item loadings in the model. Path coefficients of 0.20 and higher are assumed significant (Hair, et al., 2011). For the second stage to check the significance of structural model a bootstrapping technique is recommended with a minimum bootstrap sample of 5000. Also for a two-tailed test critical values of 1.65, 1.96 and 2.58 at the significance levels of $0.10,0.05$ and 0.01 respectively are required(Hair Jr, et al., 2016). A bootstrapping procedure with 5000 bootstrap samples at a significance level of 0.05 for twotailed test was performed. Table 1 shows the R 2 and t-values.

Results indicated that $\beta$ value of normative pressures $\rightarrow$ GSCM practices is 0.438 (t-value 6.020; $<0.0$ ); GSCM Practices $\rightarrow$ EnvtPerf 0.204 (t-value 2.158; $<<0.004$ ); GSCM Practices $\rightarrow$ EconPerf 0.070 (t-value 1.028; $<<0.313$ ); EnvtPerf $\rightarrow$ EconPerf 0.595 ( $\mathrm{t}$-value 9.275; $<<0.0$ ). It shows that other than GSCM Practices $\rightarrow$ EconPerf all path relationships were found significant.

These finding shows that all proposed hypotheses should be accepted while one hypothesis $2 \mathrm{~b}$ is rejected. These findings are consistent with the literature that normative pressures are one of the key sources for manufacturing industries to adopt GSCM practices especially in developing countries (Amer, et al., 2016, Zhu and Geng, 2013). Results also supports those stream of studies explaining that economies which are at early stage of adopting GSCM practices, they have to spend resources at start and it will not give them immediate economic benefit but in long run(Zhu, et al., 2013, Rao and Holt, 2005). Yet environmental performance can be improved straight away by adopting any of the environmental improvement practices. These practices also have direct and immediate effect on economic performance as well because of reduced waste, reduction in raw material used, improvement in work processes, sale of scrap and reuse of materials(Gopal and Thakkar, 2016, Esfahbodi, et al., 2016, Lee, et al., 2012). 


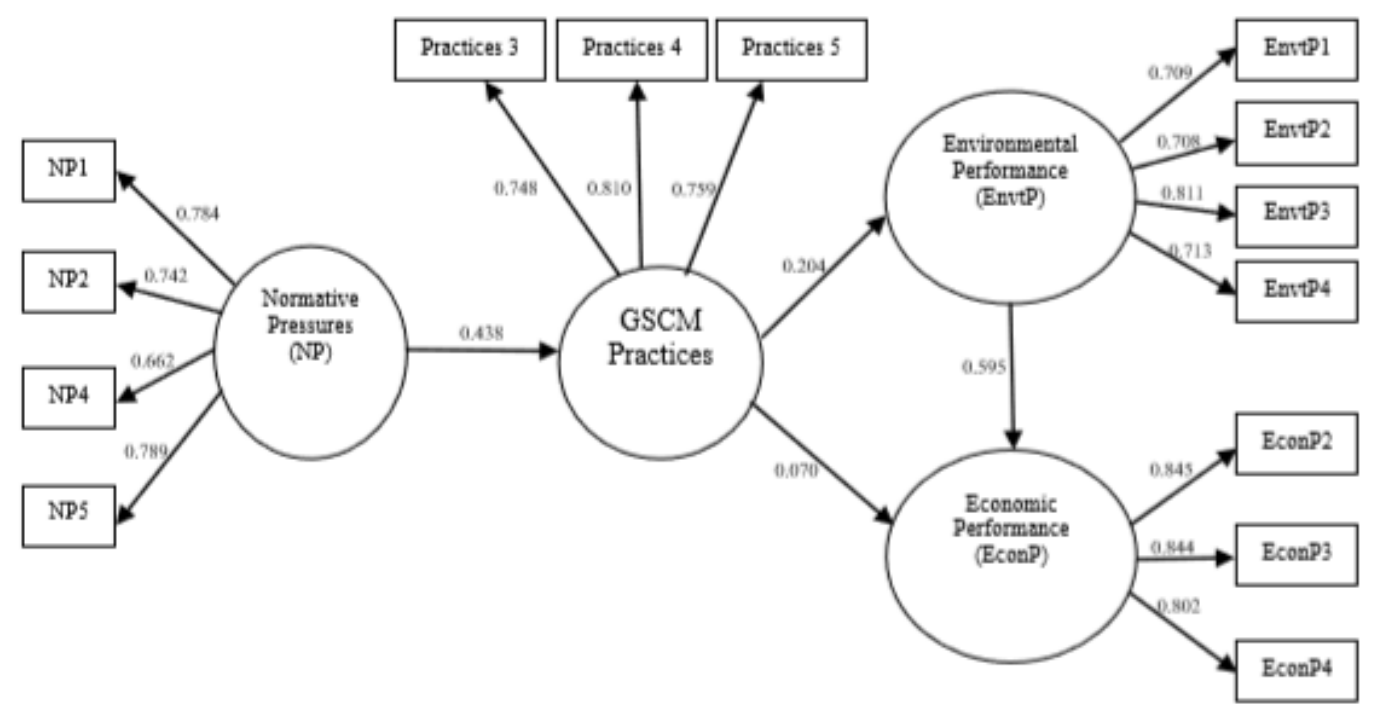

Figure 1 Structural Path Model

\section{CONCLUSION}

Environment related issues are the most important areas of research not only for current time but for the coming generations as well. More and more awareness regarding this topic is being generated and every region, country and industry should be trying to identify problems and find solutions according to local needs. This study is an attempt to find out the sequential effects of normative pressures on the adoption of GSCM practices and then the impact of GSCM practices application on the environmental and economic performance of the manufacturing companies of a developing country. The results suggested that normative pressures do have a positive significant effect on the motivation of companies to adopt GSCM practices. It is also proved that application of GSCM practices positively affects the environmental performance but no significant effect was found between GSCM practices and economic performance. This study is also in line with literature that environmental performance does improve economic performance. Therefore, managers need to have faith on their efforts to improve environment and it will also benefit financially, may not in the short run but in the long run through improved environmental performance over a period of time. This study has focused only on environmental and economic perspective. Future researches can incorporate social and operational perspectives to extend the existing study.

This study has taken a sample from only one city although it is the second largest city of Pakistan. In a future study, it would be ideal to enrich the sample by taking manufacturing companies of all industrial cities of Pakistan. Similarly, studies by focusing on complete supply chains of specific sectors can also provide more in depth analysis related to that industry which might be more helpful for the managers of that industry. 


\section{REFERENCES}

S. Amer, J. Yun, and H. P. R. Priyankara. Globalization and Green Supply Chain ManagementRole of Multinational Companies in Developing Countries from Institutional Theory Perspective[C]. in 13th International Conference on Innovation and Management (ICIM), 2016

R. Geng, S. A. Mansouri, E. Aktas. The Relationship Between Green Supply Chain Management and Performance: A Meta-Analysis of Empirical Evidences in Asian Emerging Economies[J]. International Journal of Production Economics, 2017,183:245-258

Q. Zhu, J. Sarkis, and K.-h. Lai. Institutional-Based Antecedents and Performance Outcomes of Internal and External Green Supply Chain Management Practices[J]. Journal of Purchasing and Supply Management, 2013,19(2):106-117

R. M. Vanalle, G. M. D. Ganga, M. Godinho Filho, W. C. Lucato. Green Supply Chain Management: An Investigation of Pressures, Practices, and Performance within the Brazilian Automotive Supply Chain[J]. Journal of Cleaner Production, 2017, 151:250-259

P. Gopal, J. Thakkar. Sustainable Supply Chain Practices: An Empirical Investigation on Indian Automobile Industry[J]. Production Planning \& Control, 2016, 27(1):49-64

Q. Zhu, Y. Geng. Drivers and Barriers of Extended Supply Chain Practices for Energy Saving and Emission Reduction among Chinese Manufacturers[J]. Journal of Cleaner Production, 2013,40:6-12

Q. Zhu, J. Sarkis, K.-h. Lai. Green Supply Chain Management: Pressures, Practices and Performance within the Chinese Automobile Industry[J]. Journal of Cleaner Production, 2007, 15(11):1041-1052

A. Esfahbodi, Y. Zhang, G. Watson, T. Zhang. Governance Pressures and Performance Outcomes of Sustainable Supply Chain Management-an Empirical Analysis of UK Manufacturing Industry[J]. Journal of Cleaner Production, 2016

V. Mani, A. Gunasekaran, T. Papadopoulos, B. Hazen, R. Dubey. Supply Chain Social Sustainability for Developing Nations: Evidence from India[J]. Resources, Conservation and Recycling, 2016, 111:42-52

S. U. Hoejmose, J. Grosvold, A. Millington. The Effect of Institutional Pressure on Cooperative and Coercive_Green'Supply Chain Practices[J]. Journal of Purchasing and Supply Management, 2014, 20(4):215-224

P. Rao, D. Holt. Do Green Supply Chains Lead to Competitiveness and Economic Performance?[J]. International journal of operations \& production management, 2005,25(9):898-916

S. M. Lee, S. Tae Kim, D. Choi. Green Supply Chain Management and Organizational Performance[J]. Industrial Management \& Data Systems, 2012, 112(8):1148-1180 
C. M. Ringle, Wende, S., Becker, J.-M. “"SmartPLS 3.”," ed. Boenningstedt: SmartPLS GmbH, 2015

J. F. Hair, C. M. Ringle, M. Sarstedt. PLS-SEM: Indeed a Silver Bullet[J]. Journal of Marketing Theory and Practice, 2011, 19(2):139-152

F. Hair Jr, G. T. M. Hult, C. Ringle, M. Sarstedt. A Primer on Partial Least Squares Structural Equation Modeling (PLS-SEM)[M]. ed., ed. Sage Publications, 2016

D. X. Peng, F. Lai. Using Partial Least Squares in Operations Management Research: A Practical Guideline and Summary of Past Research[J]. Journal of Operations Management, 2012. 30(6):467-480 